\title{
The Development of Tulang Bawang Local History Teaching Book to Improve Historically Thinking Skill
}

\author{
Risma Margareta Sinaga \\ Social Sciences Education \\ Lampung University \\ Lampung, Indonesia \\ risma.margaretha@fkip.unila.ac.id
}

\author{
Sugeng Widodo \\ Social Sciences Education \\ Lampung University \\ Lampung, Indonesia \\ sugeng.widodo@fkip.unila.ac.id
}

\author{
Pargito \\ Social Sciences Education \\ Lampung University \\ Lampung, Indonesia \\ pargito.1959@fkip.unila.ac.id
}

\begin{abstract}
The objective of this research was to develop Tulang Bawang local history teaching book to improve the historical thinking skill of learners in grade XI of social science. This was development research and used 5 steps of ADDIE development design: (1) analysis, (2) design, (3) development, (4) implementation, (5) evaluation. Subjects were material and media experts from the expert test subject group and 6 learners from a small group test subject. The field test was done in grade $\mathrm{XI}$ of the social sciences classroom as a treatment subject. Data were collected with questionnaires, observations, and interviews. Data were analyzed with qualitative and quantitative analyses. To find out the product effectiveness, the historical thinking skills of learners in grade XI of social sciences were compared before and after the history teaching book was developed. The research result was 1) the Tulang Bawang history teaching book, and 2) it could improve historical thinking skills. Using the developed product showed a 0.50 result difference with the moderate category, and it indicated that the developed product was effective in improving learners' historical thinking skills.
\end{abstract}

Keywords-teaching book, Tulang Bawang local history, historical thinking.

\section{INTRODUCTION}

The problem in history learning so far is that learners and teachers are not yet mastering higher-order thinking skills. Learners find difficulties in understanding and thinking about complex problems in textbooks, the bias of facts, and historical sources as is suggested by Pearcy and Gauhan [1]. Learners' shallow understanding of history lesson materials so far has been because learning in schools only transfers knowledge. History teachers are still stuck in textbooks coming from the government only. According to [2], learners should have more opportunities to be involved in authentic social study learning. Access to local history for learners is expected to be able to develop collective memories from local to national levels and to improve learners' interests in history around their environment to produce historical thinking as it is suggested by \{3].

The results of direct teaching and observation of history learning implementation in Dente Teladas 1 Public Senior High School showed profiles of history learning conditions. The Indonesia History textbook for grade XI of Senior High School Revision 2018 Edition is used as the main teaching book in learning. [4] opportunities for developing local history materials are widely opened. However, the history of the Tulang Bawang district is not yet written in the available teaching materials. A teaching book is not only used as a source, media, structure, and as an instrument for learning evaluation, but it is also expected to help learners to study autonomously, actively, and critically. However, the use of history textbooks is not optimal, monotonous, and learners consider them less interesting. Materials in the older history teaching books are less adjusted with learners' daily life realities [5].

Learners can gain learning results determined by teachers, but they ignore historical thinking skills. This fact can be shown in the results of integrated daily assessments in the odd semester of the academic year $2020 / 2021$ that $54.17 \%$ of learners did not meet passing grades, where the lowest and average scores were 27 and 66.04 respectively. The need for local history-based teaching material was supported by the results of questionnaires given to learners in grade XI of social sciences in Dente Teladas 1 Public Senior High School.

The objectives of this research were as follows:

- How did the development of Tulang Bawang local history teaching book development for grade XI of social science in Dente Teladas 1 Public Senior High School? 
- How did the effectiveness of Tulang Bawang local history teaching book develop to improve historical thinking skills of students in grade XI of social science in Dente Teladas 1 Public Senior High School?

\section{RESEARCH METHOD}

This was a research and development by using the ADDIE model (analyze, design, development, implementation, and evaluation). Data were collected by using questionnaires. Questionnaires were given to measure the properness of Tulang Bawang local history teaching book from material and learning media aspects. Students got questionnaires to obtain their responses concerning the use of the Tulang Bawang local history teaching book. Questionnaire measurement was based on the Likert scale. The result indicated that students were happy to use Tulang Bawang local history teaching book and $70.83 \%$ of them supported the development of this teaching book.

\section{RESULT AND DISCUSSION}

\section{A. Result}

Development of Tulang Bawang Local Histroy Teaching Book. The analysis activity of history learning in grade XI of social sciences in Dente Teladas 1 Public Senior High School was done by (1) analyzing Indonesia history teaching materials for grade XI of social sciences in Senior High School in curriculum 2013. Tulang Bawang history material was not yet packaged in form of interesting and systematic teaching material. (2) Analyzing the needs of learners concerning Tulang Bawang local history teaching book needs by obtaining learners' questionnaire results. $70.83 \%$ of learners supported the idea of the development of Tulang Bawang local history teaching book. (3) Looking at the integrated daily learning assessment results in the odd semester of the academic year $2020 / 2021,54.17 \%$ of learners did not pass the passing grade.

Tulang Bawang local history teaching book contained materials of West imperialism and colonialism to Nusantara archipelago. Materials in this book were focused on two aspects. They were (1) pepper trade in Tulang Bawang (1682-1911) and (2) effects of West imperialism and colonialism in Tulang Bawang. This local history teaching book was equipped with materials, summaries, students' working sheets, maps, conceptual maps, and figures. Researchers used some related references from related history books and archives from KITLV to collect data. The development of this teaching book was expected to improve learning activities and the motivations of learners to study history.

After doing an analysis, the researcher designs the product. In this process, all ideas were developed in the form of local history teaching books in form of conceptual maps, texts, maps, and figures. Materials were then composed based on syllabuses and lesson plans. The material covered in this book included West imperialism and colonialism in the Nusantara archipelago according to learning objectives in curriculum 2013. The design composed by the researcher was drawn in a storyboard consisting of (a) front book cover, (b) book contents, and (c) book back cover.

Media expert assessment to the teaching book quality in terms of media aspect was $69 \%$ so that qualitatively this teaching book belonged to "proper to use with revision" category. The lowest expert validation was from a learning material expert concerning this book's language coverage. Suggestions from learning media experts were that: 1) the size of Tulang Bawang local history teaching book should be adjusted with research instrument; 2) book proportion, color, and layout should be improved to be clearer and mutually supporting; 3 ) writing should be adjusted with the improved spelling of Indonesia language. After the researcher did improvements to Tulang Bawang local history teaching book quality based on suggestions from learning media experts, the book quality assessment improved into $80 \%$, and this book was qualitatively categorized into "very proper to use" to test in history learning.

Learning material validation by experts was done by those who had a doctoral degree in historical sciences. The assessment included the quality of Tulang Bawang local history teaching book material quality. The assessment result was $63.76 \%$, and it indicated that qualitatively this book was categorized into "proper to use with revision". Suggestions from learning material experts were: 1) to improve the title in Tulang Bawang local history teaching book according to history periodization; 2) teaching materials and sub-materials of this book should be adjusted with Indonesia history periodization. The researcher based on suggestions and comments from learning material experts change the book title into "Tulang Bawang: Pepper and Power".

Tulang Bawang local history teaching book was then tested on a small group consisting of 6 learners. Test assessment in this small group included three aspects; aspects of display, material delivery, and benefit. The aspect of material display and material delivery obtained average scores of 3.27 and 3.25 respectively and they belonged to the "very proper" category to use in history learning in the classroom. Meanwhile, the aspect of benefit obtain the lowest average score by 2.92 and it belonged to the "proper" category.

Learners' comments in the small group test toward this Tulang Bawang local history teaching book were that 1) Tulang Bawang local story teaching book was good and interesting enough to use in history learning; 2) Tulang Bawang local history teaching book would facilitate learning activities; 3 ) this local history book display was good, interesting, and it was supported with 
material explanations including conceptual maps, figures, and maps.

A big group testing was done in grade XI social science 1 classroom in Dente Teladas 1 Public Senior High School with 27 learners. Learners' assessments to Tulang Bawang local history teaching book obtain an average score of 3.01 with a "very proper" category to use in Indonesia history learning. The highest assessment score was obtained in the material delivery with an average score of 3.07 and it belonged to the "very proper" category to use in history learning. Aspects of display and benefit obtained average scores of 2.95 and 2.97 respectively and they belonged to "proper" to use.

\section{B. Discussion}

Effectiveness of Tulang Bawang Local History Teaching Book in Indonesia History Learning. The effectiveness of a local history teaching book to improve historical thinking skills was implemented in grade XI of social sciences in Dente Teladas 1 Public Senior High School with 27 learners. The effectiveness of this book could be seen from learning result average scores before and after using this teaching book. The statistic test calculation result of pretest and posttest in grade XI of social sciences is shown in the following table before:

TABLE I. PRETEST AND POSTTEST RESUlT OF GRADE XI OF THE SOCIAL SCIENCE CLASSROOM

\begin{tabular}{|l|l|l|l|l|l|l|}
\hline \multicolumn{1}{|c|}{ Test type } & learners & Passing grade & Mean & SD & Min. score & Max. score \\
\hline Pretest & 27 & 72 & 49.26 & 9.335 & 20 & 80 \\
\hline Post-test & 27 & 72 & 73.70 & 6.432 & 59 & 100 \\
\hline
\end{tabular}

The normalized n-gain result of the learner's cognitive learning result was averagely 0.48 . According to Hake criteria [6], that the learner's cognitive learning result indicated a "moderate" category. Pretest and posttest score data were distributed normally and homogeneously so that analysis was continued with a one-way ANOVA test. The test result derived $\mathrm{t}=$ 23.352 with probability 0.04 (p-value $<0.05$ ), so that H0 was accepted. Data showed that those two groups had a significant value less than 0.05 . $\mathrm{H}_{0}$ was accepted, or there was a difference before and after the Tulang Bawang history teaching book was implemented. Therefore, the learning results obtained by learners in grade XI of social science 1 after using the Tulang Bawang local history teaching book were better than before using the book

This research finding in using Tulang Bawang local history book teaching to improve historical thinking skills was following the research [8] entitled The Enhancement of Attractiveness and Effectiveness of History Learning Using Local History Interactive Teaching Material. Her finding revealed that local history interactive teaching material was also effective in improving learners' knowledge about local history in Jember with a high effectiveness category by $72.68 \%$.

The observation results of learning activities and implementation of learning evaluations indicated that using Tulang Bawang local history teaching book contributed to the learning process in improving learners' historical thinking skills and activities. This could be seen from a better classroom organization to be more conducive from each of the ends of learning activities, despite some noticeable notices to concern. After teachers used Tulang Bawang local history teaching book in learning activities in grade XI of social science 1 classroom, 1) learners could think openly and they felt being more interactive in the learning process; 2) learners tried more to express their opinions and their curiosities went deeper concerning presented materials in Tulang Bawang local history; 3) learners understood more the historical plot that was taught and the way to interconnect data, sources, and historical facts; 4) the teacher's role as a facilitator grew bigger where the teacher only presented a material outline for about 5 minutes and then learners would take more roles in learning.

Effectiveness of Local History Teaching Book in Improving Historical Thinking Skill. The historical thinking skill was observed from learning activities in the classroom. The teacher divided the classroom into five heterogeneous groups. The result of historical thinking skill assessment based on learning activities of those five groups are presented in the following table below:

TABLE II. ASSESSMENT RESULT OF HISTORICAL THINKING IN GRADE XI OF SOCIAL SCIENCES 1 CLASSROOM

\begin{tabular}{|l|l|l|l|l|l|l|}
\hline Historical Thinking Indicator & Group 1 & Group 2 & Group 3 & Group 4 & Group 5 & Avg. \\
\hline Chronological thinking & 75 & 75 & 75 & 75 & 85 & 77 \\
\hline History understanding & 79.17 & 79.17 & 75 & 75 & 75 & 76.67 \\
\hline History interpretation analysis & 60 & 60 & 65 & 60 & 65 & 62 \\
\hline Conducting history research & 70 & 70 & 55 & 65 & 60 & 64 \\
\hline Analyzing issue and decision making & 66.67 & 58.33 & 58,33 & 58.83 & 50 & 58.43 \\
\hline
\end{tabular}


Observation results of historical thinking from five groups showed that the highest score was obtained in chronological thinking indicator by $77 \%$, then followed by history understanding indicator by $76.67 \%$, analysis and history interpretation by $62 \%$, conducting history research by $64 \%$, analyzing issue and decision making by $58.43 \%$. The average historical thinking score of learners in grade XI of social sciences 1 classroom could be categorized into the "good" category. This indicated that using Tulang Bawang's local history teaching book was more effective in improving historical thinking skills compared to conventional learning. In addition, the book also provided a more concrete learning experience for learners where they could use learning sources interactively, autonomously, and cooperatively.

Learners' historical thinking skills improved into the "very good" category. This was because in the learning process learners tried to develop their thinking skills by relating materials with the experimental activities that they experienced. This supports research by [8] entitled "controversial issues based history learning model to improve students' historical thinking (a study on students in Muhammadiyah University in Purwokerto), that the significant influence toward the developed model related to controversial issues was used to improve historical thinking.

\section{CONCLUSION}

This Tulang Bawang local history teaching book development included analysis, design, development, implementation, and evaluation. Data validation from learning media experts obtained $80 \%$ with the" very proper to test" category. Learning material validation result obtained $80 \%$ with "very proper to use" in history learning. A test for a small group containing 6 learners obtained a score of 3.15 with the "very proper" category. Test result with a big group consisting of learners of grade XI of social sciences 1 classroom obtained score 3.01 with "very proper to use" category for Indonesia history learning in Dente Teladas 1 Public Senior High School.

The development of Tulang Bawang local history teaching book could improve historical thinking skills and it was indicated by $n$-gain 0.48 that was interpreted into "moderate" category. Therefore, the learning result obtained by grade XI of social sciences 1 classroom after using Tulang Bawang local history teaching book was better than before using the book.

Using the Tulang Bawang local history teaching book to improve the historical thinking skill of learners in Dente Teladas 1 Public Senior High School was proven to be effective. The historical thinking of those learners was obtained from observations to historical thinking skill indicators at five groups. The highest result was chronological thinking indicator by $77 \%$, then followed by history understanding by $76.7 \%$, history research by $64 \%$, while the lowest was analyzing issues and decision-making by $58.43 \%$. The development of this Tulang Bawang local history teaching book was limited to West imperialism and colonialism material, and it was to be expected to develop with other local history teaching materials.

\section{REFERENCES}

[1] Mahzan Awang, Mohd Dkk, 'Historical Thinking Skills Among Pre-Service Teachers In Indonesia And Malaysia,' Creative Education, Vol. 7, 2016, doi: 10.4236/ce.2016.71007.

[2] M. Waring, Scott \& Kirk S. Robinson, 'Developing Critical and Historical Thinking Skills in Middle Grades Social Studies,' Middle School Journal. Vol. 42, issue 1, pp. 22-28, 2010, doi: 10.1080/00940771.2010.11461747.

[3] Hasan, Hamid, 'Kurikulum Pendidikan Sejarah Berbasis Kompetensi'. Makalah. File.Upi.edu, 2007.

[4] Permendikbud No 24 tahun 2016 tentang Kompetensi Dasar Kurikulum 2013 SMA/MA/SMK

[5] U. Krismawati, 'Kebutuhan Bahan Ajar Sejarah Lokal Di Sma,' Cendekia, Vol. 16 No 2, pp. 355-375, 2018.

[6] Hake, R.R, 'Analyzing Changes Gain Score,' Indiana University Usa(Online), 1999, http://www.physics.indiana.edu/ sdi/Analyzing ChangeGain.pdf, accssed 10 August 2015

[7] Maunah,Siti dkk, 'The Enhancement of Attractiveness and Effectiveness of History Learning Using Local History Interactive Teaching Material,' American Journal of Educational Research ·Vol. 6, No. 11, 1531-1538, 2918.

[8] Septianingsih, Sumiyatun Dkk, 'Model Pembelajaran Sejarah Berbasis Isu-Isu Kontroversial Untuk Meningkatkan Berpikir Historis Mahasiswa (Studi Pada Mahasiswa Sejarah Univ. Muhammadiyah Purwokerto),' Historika, Vol.15, No. 2, pp, 98-109, 2014 